\title{
ANALISIS POTENSI PAJAK DAERAH DI KOTA JAMBI
}

\author{
Rahayu ${ }^{1)}$, Salman Jumaili ${ }^{2)}$ Kamadie Sumanda $S^{3)}$ \\ ${ }^{1,2,3)}$ Dosen Fakultas Ekonomi dan Bisnis Universitas Jambi \\ rahayu-fe@unja.ac.id;
}

\begin{abstract}
This study aims to analyze the potential of local taxes in Jambi City. This research is a kind of quantitative descriptive research by explaining and analyzing the data that has been obtained. The data used is data on the Jambi City Gross Regional Domestic Product (GRDP) from 2012-2016. The results showed that the GRDP of Jambi City increased every year, and all sectors also experienced an increase except the mining sector. The highest GRDP is in the free and retail trade category, while the lowest GRDP is in the category of electricity and gas procurement. The results of the Klassen Typology Analysis show that GRDP is grouped into 2 (two) sectors, namely the leading sector and underdeveloped sector. Sectors included in the underdeveloped sector are the Agriculture, Forestry, Fisheries and Mining and Excavation sectors. While other sectors are included in the leading sector. Jambi City regional taxes always increase each year based on 2012-2016 tax revenue data. The highest tax is obtained from street lighting tax, BPHTB, and restaurant tax.
\end{abstract}

Keywords: Local Tax, PDRB, Potency.

\begin{abstract}
ABSTRAK
Penelitian bertujuan untuk melakukan analisis adanya potensi pajak daerah di Kota Jambi. Penelitian ini merupakan jenis penelitian deskriptif kuantitatif dengan menjelaskan dan menganalisis data-data yang telah diperoleh. Untuk melakukan penelitian ini, digunakan data Produk Domestik Regional Bruto (PDRB) Kota Jambi dari tahun 20122016. Hasil penelitian menunjukkan bahwa PDRB Kota Jambi mengalami kenaikan setiap tahunnya, dan semua sektor juga mengalami kenaikan kecuali sektor pertambangan. PDRB tertinggi berada pada kategori perdagangan bebas dan eceran, sedangkan PDRB terendah berada pada kategori pengadaan listrik dan gas. Hasil Analisis Tipologi Klassen menunjukkan bahwa PDRB terkelompok menjadi 2 (dua) sektor, yaitu sektor unggulan dan sektor terbelakang. Sektor yang termasuk dalam sektor terbelakang adalah sektor Pertanian, Kehutanan, Perikanan serta sektor Pertambangan dan Penggalian. Sedangkan sektor yang lain masuk dalam sektor unggulan. Pajak daerah Kota Jambi selalu mengalami kenaikan tiap tahunnya berdasarkan pada data penerimaan pajak tahun 2012-2016. Pajak tertinggi diperoleh dari pajak penerangan jalan, BPHTB, dan pajak restoran.
\end{abstract}

Kata kunci : Pajak Daerah, PDRB, Potensi. 


\section{PENDAHULUAN}

\subsection{Latar Belakang}

Pelaksanaan otonomi daerah yang diterapkan oleh pemerintah berdasarkan Undang-Undang Nomor 33 Tahun 2004 menyatakan bahwa yang merupakan sumber-sumber penerimaan daerah adalah penerimaan yang diterima daerah dari pendapatan asli daerah, transfer dana dari pemerintah pusat, transfer dana dari pemerintah provinsi dan lain-lain. Penerimaan yang berasal dari daerah sendiri berupa Pendapatan Asli Daerah terdiri dari: (1) pajak yang diterima daerah, (2) retribusi yang dipungut oleh daerah, (3) keuntungan yang diperoleh oleh perusahaan milik daerah dan hasil pengelolaan kekayaan daerah yang dipisahkan, (4) lain-lain pendapatan asli daerah yang sah.

Perimbangan keuangan pusat dan daerah telah diatur dengan jelas pada pasal 1 UU No 33 Tahun 2004. Keseluruhan dana yang diterima oleh daerah yang berasal dari sumber-sumber pengelolaan mandiri daerah disebut sebagai PAD. Bentuk sumber pengelolaan mandiri tersebut antara lain hasil retribusi daerah, pajak-pajak yang diterima daerah sesuai kewenangannya, dana yang berasal dari pinjaman (apabila dianggap perlu oleh daerah), dan sumber pendapatan lain seperti hibah. Dana yang diperoleh dari pengelolaan mandiri daerah yang disebut PAD ini merupakan salah satu komponen penerimaan dari Anggaran Pendapatan Belanja Daerah (APBD).

Dalam rangka meningkatkan PAD maka ditetapkanlah peraturan mengenai penerimaan daerah yang diperoleh dari sumber Pajak dan Retribusi Daerah. Aturan tersebut tertuang dalam Undang-Undang Nomor 28 Tahun 2009. Berdasarkan pada UU tersebut, yang dimaksud dengan Pajak Daerah adalah kontribusi wajib pajak perorangan atau badan usaha kepada daerahnya yang berdasarkan Undang - undang dengan sifat dapat dipaksakan, yang digunakan oleh daerah untuk sebesarbesarnya kemakmuran rakyat, dengan tidak memberikan imbalan langsung kepada wajib pajak tersebut.

Pajak yang dipungut tersebut merupakan dana yang dikelola oleh daerah untuk meningkatkan pendapatan daerah. Pajak tersebut dikelompokkan menjadi pajak propinsi dan pajak kabupaten. Dengan adanya peningkatan penerimaan negara dari pajak, akan berdampak pada meningkatnya pembiayaan yang dikeluarkan oleh daerah untuk membiayai kegiatankegiatan daerah dengan tetap pada satu tujuan yaitu untuk meningkatkan kesejahteraan masyarakat daerahnya.

Kontribusi penerimaan pajak terhadap penerimaan Negara diharapkan semakin meningkatkan dari tahun ke tahun. Salah satu upaya dalam meningkatkan kepatuhan wajib pajak adalah memberikan pelayanan yang baik kepada wajib pajak. Peningkatan kualitas dan kuantitas pelayanan diharapkan dapat meningkatkan kepuasan kepada wajib pajak sebagai pelanggan sehingga meningkatkan kepatuhan dalam bidang perpajakan.

Propinsi Jambi merupakan bagian dari pemerintahan di Indonesia. Provinsi Jambi serta
Kabupaten Kota di bawahnya juga melakukan pengumpulan dana dari masyarakat dalam bentuk pajak dan menyalurkannya kembali ke masyarakat salah satunya untuk meningkatkan pelayanan publik.

Salah satu pemerintah daerah yang terdapat di Provinsi Jambi adalah Kota Jambi. Kota Jambi merupakan Kota yang pertama kali dibentuk di Propinsi Jambi. Kota Jambi juga merupakan pusat bisnis terbesar di Provinsi Jambi. Pengelolaan pajak daerah yang baik sangat diharapkan masyarakat agar potensi pajak yang dimiliki dapat dianalisis dan dikelola dengan baik dan memberikan dampak kepada masyarakat.

Penerimaan pendapatan Kota Jambi dari Pajak daerah masih belum mencapai hasil yang maksimal. Pada tahun 2016, anggaran dan realisasi pajak terlihat pada tabel di bawah ini:

\section{Anggaran dan Realisasi Pajak Daerah Kota Jambi Tahun 2016 dan 2015}

\begin{tabular}{|l|l|r|r|r|r|}
\hline NO & \multicolumn{1}{|c|}{ URAIAN } & \multicolumn{1}{c|}{ ANGGARAN } & \multicolumn{1}{c|}{ REALISASI } & \multicolumn{1}{c|}{$\%$} & \multicolumn{1}{c|}{ REALISASI 2015 } \\
\hline & PENDAPATAN PAJAKDAERAH & 187.252 .000 .000 & 158.740 .884 .099 & 84,77 & 147.889 .448 .423 \\
\hline 1 & Pajak Hotel & 10.500 .000 .000 & 9.559 .528 .743 & 91,04 & 6.929 .780 .174 \\
\hline 2 & Pajak Restoran & 19.250 .000 .000 & 20.746 .469 .310 & 107,77 & 16.743 .102 .485 \\
\hline 3 & Pajak Hiburan & 7.500 .000 .000 & 7.673 .051 .524 & 102,31 & 6.119 .125 .119 \\
\hline 4 & Pajak Reklame & 10.000 .000 .000 & 8.475 .131 .873 & 84,75 & 6.000 .440 .224 \\
\hline 5 & Pajak Penerangan Jalan & 61.100 .000 .000 & 53.976 .543 .388 & 88,34 & 52.228 .706 .863 \\
\hline & Pajak Mineral Bukan Logam & & & & \\
6 & dan Batuan & 250.000 .000 & 168.565 .000 & 67,43 & 189.350 .000 \\
\hline 7 & Pajak Parkir & 3.500 .000 .000 & 3.206 .248 .195 & 91,61 & 2.179 .089 .556 \\
\hline 8 & Pajak Air Tanah & 130.000 .000 & 184.155 .167 & 141,66 & 135.932 .612 \\
\hline 9 & Pajak Sarang Burung Walet & 22.000 .000 & & 0.00 & \\
\hline 10 & Pajak Bumi dan Bangunan & 30.000 .000 .000 & 18.179 .644 .803 & 60,60 & 19.628 .912 .994 \\
\hline 11 & BPHTB & 45.000 .000 .000 & 36.571 .546 .096 & 81,27 & 37.735 .008 .396 \\
\hline
\end{tabular}

Berdasarkan pada tabel di atas, terlihat bahwa secara keseluruhan total realisasi Pendapatan Pajak Daerah 2016 hanya sebesar 84,77\%. Secara rinci terlihat bahwa masih terdapat pajak-pajak yang belum mencapai target yang telah dianggarkan. Berdasarkan data tersebut, maka perlu dilakukan analisis lebih lanjut terkait dengan potensi yang dimiliki oleh Kota Jambi, hingga menghitung potensi pajak daerah yang dimiliki serta menentukan strategi dalam mengelola pajak daerah sehingga dapat memperoleh hasil yang maksimal. Dalam rangka meningkatkan potensi pajak di Kota Jambi tersebut, maka dilakukan penelitian dengan judul "ANALISIS POTENSI PAJAK DAERAH DI KOTA JAMBI”.

\subsection{Rumusan Masalah}

Berdasarkan latar belakang $\mathrm{di}$ atas dapat dirumuskan masalah penelitian pada penelitian ini sebagai berikut:

1. Bagaimana potensi pendapatan daerah di Kota Jambi?

2. Bagaimana pengelompokan sektor-sektor pendapatan yang ada di Kota Jambi berdasarkan pada Analisis Tipologi Klassen?

3. Bagaimana penerimaan daerah dari sektor pajak Kota Jambi berdasarkan pada laporan hasil audit BPK? 


\section{TINJAUAN PUSTAKA, PEMIKIRAN DAN HIPOTESIS \\ KERANGKA}

\subsection{Tinjauan Pustaka}

\subsubsection{Pengertian Pajak}

Menurut Prof. Dr. Rochmat Soemitro, SH" (dalam Mardiasmo: 2011) :

"Pajak merupakan iuran yang dibayarkan oleh rakyat kepada Negara dengan berdasarkan kepada Undang-undang. Pemungutan ini bersifat dapat dipaksakan oleh pemerintah dengan tidak memberikan imbalan jasa atas pembayaran oleh masyarakat tersebut (tidak adanya kontra prestasi langsung)."

Sedangkan menurut P. J. A. Andriani (dalam Waluyo, ,2009)

"Pajak merupakan iuran dari masyarakat kepada Pemerintah Indonesia Negara (dengan sifat dapat dipaksakan) serta terutang kepada pihak-pihak yang wajib membayarnya menurut peraturan perundangundangan yang berlaku dengan tidak memberikan imbalan langsung tapi ditunjukkan dengan pembiayaan untuk membiayai seluruh pengeluaran-pengeluaran negara yang bersifat umum.

\subsubsection{Pajak Daerah}

Pajak daerah yang merupakan salah satu jenis pajak yang dipungut oleh pemerintah, merupakan kontribusi yang diberikan oleh wajib pajak pribadi maupun badan usaha kepada daerahnya dengan berdasarkan pada undang-undang dengan sifat yang dapat dipaksakan tanpa memberikan imbalan langsung atas kontribusinya tersebut. Pajak yang dibayarkan akan digunakan untuk membiayai pembelanjaan daerah dengan tujuan meningkatkan kesejahteraan rakyat di daerahnya.

Jenis-jenis pajak daerah adalah sebagai berikut:

1. Pajak Hotel;

Yang dimaksud dengan hotel adalah penyedia yang memberikan fasilitas berupa tempat penginapan dengan meminta bayaran atas jasa yang diberikannya tersebut. Usaha penginapan lain yang termasuk dalam kategori hotel adalah rumah kos-kos-an yang memiliki kamar lebih dari 10 (sepuluh), motel, wisma pariwisata, atau losmen.

Penyedia jasa yang menyediakan jasa tersebut di atas akan dikenakan pajak hotel atas pelayanan yang diberikannya.

2. Pajak Restoran;

Pajak Restoran merupakan pajak yang dipungut kepada pihak yang menyediakan jasa untuk menyediakan makanan/minuman kepada pihak lain. Penyediaan tersebut akan dipungut bayaran oleh pihak penyedia. Yang masuk kategori restoran diantaranya adalah kantin, warung, cafe, katering/boga, serta rumah makan dan jenis lainnya yang memberikan layanan yang sama.
3. Pajak Hiburan;

Pajak ini dikenakan atas semua bentuk hiburan yang diberikan kepada masyarakat dengan mengambil bayaran atas hiburan yang diberikan tersebut. Hiburan yang diberikan bisa dalam bentuk pertunjukan musik, hiburan pasar malam dan sejenis lainnya.

4. Pajak Reklame;

Pajak yang dibayarkan atas kegiatan ini adalah adanya kegiatan dalam rangak untuk memperkenalkan sesuatu hal, mengajak atau mempromosikan suatu barang dengan tujuan agar orang lain tertarik untuk mengikuti apa yang tertera pada ajakan tersebut. Kegiatan ini disebut reklame dan pajak yang terutangnya disebut pajak reklame.

5. Pajak Penerangan Jalan;

Pajak ini dikenakan atas adanya penggunaan watt listrik untuk menerangi jalan, baik buatan sendiri atau berasal dari sumber lainnya.

6. Pajak Mineral Bukan Logam dan Batuan;

Kegiatan untuk melakukan pengambilan sumber alam berupa mineral tetapi bukan logam atau batuan akan dikenakan Pajak Mineral Bukan Logam dan Batuan. Namun berdasarkan peraturan per undang-undang, sejak 2017, pemerintah Kota Jambi dilarang untuk melakukan pungutan atas pajak ini.

7. Pajak Parkir;

Penyelenggaraan parkir dengan menggunakan badan jalan daerah akan dikenakan tarif pajak parkir. Pengenaan ini dikenakan untuk kegiatan penitipan kendaraan bermotor yang melakukan pemungutan kepada pemakai.

8. Pajak Air Tanah;

Pajak ini adalah pengenaan pajak atas diambilnya manfaat air tanah oleh pihak tertentu.

9. Pajak Sarang Burung Walet.

Pajak ini dikenakan untuk kegiatan yang dilakukan dengan melakukan pengambilan sarang burung walet.

\subsubsection{Analisis Potensi Pendapatan Pajak Daerah}

\section{Potensi Pendapatan}

Potensi adalah sesuatu yang sebenarnya sudah ada, hanya belum didapat atau diperoleh di tangan. Untuk mendapatkan atau memperolehnya diperlukan upaya-upaya tertentu, misalnya untuk potensi sumber daya alam tambang perlu upaya eksplorasi dan eksploitasi, untuk potensi pajak perlu dilakukan upaya pajak (tax effor). Karena potensi tersebut sifatnya masih tersembunyi, maka perlu diteliti besarnya potensi pendapatan yang ada. Analisis potensi pendapatan bersifat luas sebab banyak faktor yang harus diidentifikasi terkait dengan pendapatan. Identifikasi faktor-faktor yang mempengaruhi pendapatan merupakan bagian dari upaya mengenali potensi pendapatan. Bagi manajer publik, kemampuan mengenali potensi pendapatan dan memanfaatkannya secara optimal merupakan hal penting yang 
menunjukkan kapasitas enterpreneurship mereka dalam mengelola organisasi sektor publik. Osborne dan Gaebler menyatakan pentingnya menumbuhkan pemerintahan wirausaha membelanjakan anggaran (earning rather than spending). Menumbuhkan birokrasi wirausaha ini merupakan tantangan bagi manajer publik, terutama kepala daerah pejabat terkait di lingkungan pemerintahan daerah. (Mahmudi, 2010).

Salah satu cara yang bisa dilakukan oleh pimpinan daerah untuk memahami dan mengenal potensi pendapatan daerahnya adalah dengan melakukan perhitungan penggalian informasi terkait Produk Domestik Bruto (PDB). (Mahmudi, 2010).

\section{Pemetaan Potensi Pendapatan}

Tingkat perekonomian daerah memiliki sumber dan hasil yang berbeda-beda, hal ini tergantung kepada potensi yang dimiliki oleh daerah tersebut. Perbedaan salah satunya bisa terjadi karena kondisi demografi, sosial budaya, faktor ekonomi maupun faktor-faktor lainnya. Potensi-potensi ini harus dapat dikelola dengan baik oleh pemerintah daerah agar peningkatan perekonomian dapat tercapai. Namun demikian, tidak semua daerah mampu mengelola potensi yang dimilikinya dengan baik, sehingga terkadang potensi tersebut menjadi tidak ter manfaatkan dengan baik, bahkan terkadang malah menjadi beban di daerah tersebut. Salah satu yang menjadi penyebab adalah keterbatasan sumber daya yang dimiliki untuk mengelola potensi daerah tersebut. Potensi daerah secara garis besarnya dapat digolongkan menjadi: (Mahmudi, 2010)

1. Daerah dengan potensi dan kemampuan mengelola potensi daerahnya yang tinggi.

2. Daerah dengan potensi daerah yang tinggi tetapi kemampuan untuk mengelola potensi tersebut rendah.

3. Daerah dengan potensi daerah yang rendah tetapi memiliki kemampuan mengelola yang tinggi.

4. Daerah dengan potensi daerah yang rendah dan kemampuan mengelola potensinya juga rendah.

Pengelompokan potensi pendapatan daerah dan kemampuan untuk mengelola potensi tersebut dapat terlihat pada gambar di bawah ini:

Gambar 1.

Peta Potensi Daerah

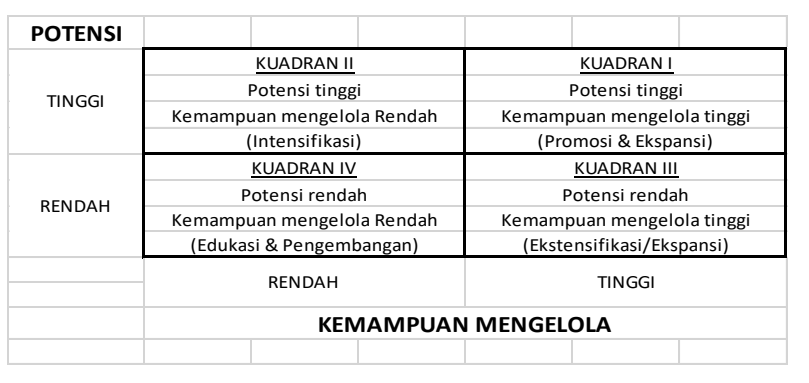

Kuadran I merupakan kondisi terbaik, karena suatu daerah memiliki potensi pendapatan yang besar dan pemerintah daerah mampu untuk mengelola potensi tersebut dengan sangat baik.

Pada kondisi ini yang perlu dilakukan adalah menjaga sumber pendapatan untuk kesinambungan fiskal antar generasi. Dengan kemampuan mengelola yang tinggi tidak berarti potensi yang ada harus dieksploitasi seluruhnya saat ini sehingga mengakibatkan generasi berikutnya tidak lagi menikmati potensi pendapatan tersebut. Hal ini khususnya terkait dengan potensi ekonomi dari sumber daya alam yang tidak terbarui, seperti barang tambang.

Kuadran II merupakan suatu kondisi dari suatu daerah yang memiliki kualitas SDM untuk mengelola potensi daerah secara memadai, namun masih belum mampu mengelola seluruh potensi pendapatan daerah yang sangat tinggi. Indonesia secara negara masuk dalam kondisi kuadran ini, dan biasanya kondisi ini adalah negara-negara berkembang. Kondisi pada kuadran II ini cukup rawan karena dapat dijadikan peluang oleh pihak asing dengan kemampuan kompetensi yang lebih tinggi untuk meng-eksploitasi (memanfaatkan) potensi daerah yang tidak dapat dikelola dengan baik oleh pemerintah daerah.

Langkah yang paling efektif untuk mengatasi kondisi pada kuadran ini adalah perlunya sikap patriotisme dan nasionalisme ekonomi, yaitu motivasi pribadi untuk dapat memberikan kontribusi dan menggunakan potensi daerah untuk meningkatkan perekonomian daerah sehingga dapat digunakan untuk meningkatkan kesejahteraan masyarakat sehingga generasi di masa mendatang dapat menikmati hasil dari potensi daerah tersebut. Beberapa Strategi pengelolaan yang dapat dilakukan adalah:

a. Mengelola pendapatan secara berkala dan berkesinambungan.

b. Melakukan kerjasama dengan pihak ketiga untuk mengelola sumber daya secara Bersama.

c. Joint venture dengan investor

d. Memberikan Pendidikan dan pelatihan untuk meningkatkan sumber daya manusia.

Kuadran III merupakan kondisi daerah yang pada dasarnya memiliki kemampuan mengelola potensi daerah yang tinggi, tetapi sumber daya alam dan potensi daerahnya cukup rendah. Dengan kondisi seperti ini, maka pimpinan daerah harus melakukan strategi antara lainnya adalah ekstensifikasi atau ekspansi. Contohnya adalah Daerah Istimewa Yogyakarta yang tidak memiliki potensi hutan ataupun sumber daya alam yang tinggi, namun daerah ini mampu menghasilkan banyak produk yang berasal dari sumber tersebut. Dengan melakukan strategi yang tepat, maka sektor yang masuk dalam Kuadran III, bisa naik mencapai Kuadran II dan bahkan mencapai Kuadran I.

Kuadran IV merupakan suatu kondisi yang harus dihindari oleh pemerintah daerah, dikarenakan pada 
kuadran ini, potensi daerah sangat rendah dan upayaupaya yang dilakukan oleh pemerintah tidak mampu untuk meningkatkan kontribusi terhadap perekonomian. Hal ini dikarenakan pemerintah daerah tidak mampu untuk mencari strategi terbaik dan tidak memiliki sumber daya manusia yang komepten.

Untuk memperbaiki kondisi ini, maka pemerintah harus mencari strategi untuk meningkatkan kualitas masyarakatnya melalui program pendidikan dan pelatihan sehingga kualitas dan kuantitas pihak yang mengelola potensi pendapatan darah akan meningkat. Peran pemimpin daerah juga akan sangat penting, karena kepala daerah akan memegang peran penting untuk mengarahkan seluruh strategi dan rencana kerja agar seluruh sektor mampu naik tingkat mencapai kuadaran III.

\section{Analisis Tipologi Klassen}

Potensi daerah secara sektoral dapat dikelompokkan atau dipetakan dengan menggunakan data PDRB. Data tersebut dapat dianalisis dengan menggunakan analisis Tipologi Klassen. Berdasarkan pada analisis ini, pengelompokan dilakukan dengan melihat tingkat pertumbuhan dan kontribusi suatu sektor terhadap PDRB daerah tersebut. Hasil dari perhitungan tersebut akan mengelompokkan sektorsektor menjadi 4 (empat) sektor, yaitu:

1. Sektor prima (unggulan)

Sektor ini merupakan sektor yang paling banyak memberikan kontribusi dalam meningkatkan perekonomian daerah, dan pertumbuhannya juga paling tinggi.

2. Sektor potensial

Sektor ini merupakan sektor yang memberikan kontribusi tinggi terhadap perekonomian suatu daerah, tetapi tingkat pertumbuhannya tidak secepat sektor prima dan terkadang cenderung menurun. Laju pertumbuhannya juga lebih lambat.

3. Sektor berkembang

Sektor ini merupakan sektor yang sedang mengalami kenaikan dan mampu memberikan pertumbuhan yang tinggi terhadap perekonomian daerah. Tetapi kontribusi yang diberikan oleh sektor ini masih rendah.

\section{Sektor terbelakang}

Sektor ini merupakan sektor yang ditunjukkan dengan tingkat pertumbuhan yang lambat dan tingkat kontribusi yang cukup rendah terhadap PDRB daerah. Sektor ini akan menjadi kelemahan bagi daerah dalam meningkatkan perekonomiannya.

Hasil dari pemetaan potensi daerah akan mempengaruhi kebijakan keuangan yang akan diambil oleh kepala daerah. Hal ini sebagai salah satu upaya untuk meningkatkan perekonomian daerah. Untuk sektor unggulan, maka pemerintah harus dapat mempertahankan agar seluruh sektor yang masuk dalam kategori ini tetap berada pada sektor tersebut, dikarenakan sektor ini merupakan sektor unggulan. Oleh karena itu, stabilitas pertumbuhannya harus dijaga, karena jika tidak dikelola dengan baik, maka sektor ini akan menurun tingkat pertumbuhannya dan menggeser sektor tersebut menjadi sektor potensial.

Dalam mencari strategi untuk menghadapi sektor berkembang, maka pemerintah harus mengambil langkah optimalisasi dengan cara intensifikasi. Sektor ini akan menjadi peluang bagi daerah untuk dapat ditingkatkan lagi sehingga memberikan kontribusi kepada PDRB daerah dan menaikkan sektor unggulan. Tetapi jika sektor tersebut tidak dikelola dengan baik, maka akan menyebabkan sektor tersebut menjadi sektor terbelakang.

Sektor potensial harus dikelola dengan baik dengan cara melakukan pembenahan dan pembinaan yang baik, karena sektor ini akan memberikan kontribusi dan pembenahan sebab sektor potensial ini memberikan kontribusi yang besar bagi perekonomian daerah tetapi pertumbuhannya sudah mulai menurun. Jika sektor potensial ini tidak mendapat perhatian, maka bisa jadi sektor ini akan berubah menjadi sektor terbelakang.

Kelompok sektor yang masuk dalam sektor terbelakang harus dapat diselesaikan dengan cepat oleh pemerintah, dikarenakan sektor ini dapat mengurangi pencapaian perekonomian daerah. Sektor ini cukup sulit untuk dinaikkan tingkat menjadi sektor berkembang atau sektor lainnya.

Pengelompokan suatu sektor kedalam 4 kategori Tipologi Klassen dihitung berdasarkan pada perhitungan tingkat laju pertumbuhan kontribusi sektoral dan rerata besar kontribusi sektoralnya terhadap PDRB, seperti yang ditunjukkan tabel berikut:

\section{Gambar 2}

Matriks Analisis Tipologi Klassen

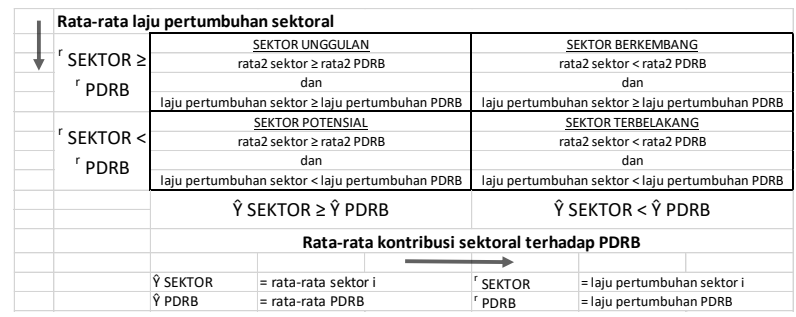

Untuk melakukan analisis tipologi klassen, langkah-langkah yang dilakukan adalah:

1. Menghitung rata-rata tingkat PDRB per sektor.

2. Menghitung rata-rata sektor.

3. Menghitung tingkat laju pertumbuhan PDRB .

4. Mengklasifikasikan masing-masing sektor ke dalam matriks. 


\section{METODOLOGI PENELITIAN}

\subsection{Objek Penelitian}

Penelitian ini dilaksanakan dengan objek penelitian di Kota Jambi.

\subsection{Metode Penelitian}

Penelitian ini merupakan penelitian dengan bentuk deskriptif kuantitatif karena penelitian menjelaskan dan menganalisis data-data yang telah diperoleh.

\subsection{Metode Pengumpulan Data}

Data yang digunakan adalah data sekunder. Data sekunder yang digunakan dalam penelitian ini adalah:

1. Data PDRB Kota Jambi untuk tahun 2012-2016 dari semua sektor yang ada di Kota Jambi.

2. Data hasil audit BPK tahun 2012-2017.

\subsection{Teknik Analisis Data}

Penelitian ini dilakukan untuk melihat potensi pendapatan yang ada di Kota Jambi secara makro. Untuk melakukan analisis ini, maka digunakan data Produk Domestik Regional Bruto (PDRB) untuk 5 (lima) tahun terakhir, dengan langkah-langkah analisis sebagai berikut:

\section{Mengenali potensi pendapatan}

Pada tahap ini, dilakukan untuk mengetahui potensi pendapatan yang ada di Kota Jambi, dengan menggunakan data PDRB dari berbagai sektor.

2. Melakukan analisis Tipologi Klassen

Langkah-langkah dalam melakukan analisis Tipologi Klassen, yaitu:

a. Menghitung rata-rata PDRB per sektor

b. Menghitung rata-rata sektor

c. Menghitung laju pertumbuhan PDRB dan juga laju pertumbuhan masing-masing sektor

d. Mengklasifikasikan masing-masing sektor ke dalam matriks kategori, yaitu:

1) Sektor unggulan (prima)

2) Sektor potensial

3) Sektor berkembang

4) Sektor terbelakang

3. Membandingkan hasil Analisis Tipologi Klassen dengan realisasi pajak daerah berdasarkan Laporan Keuangan Pemerintah Kota Jambi berdasarkan hasil Audit BPK.

4. Merumuskan strategi untuk pengelolaan pajak dengan konsep manajemen pengelolaan pajak daerah.

\section{HASIL DAN PEMBAHASAN}

\subsection{Potensi Pendapatan Di Kota Jambi}

Potensi pendapatan di Kota Jambi bisa terlihat pada Produk Domestik Regional Bruto (PDRB) sejak tahun 2012-2016. PDRB Kota Jambi mengalami peningkatan setiap tahunnya dengan nilai tertinggi berada pada tahun 2016. Rata-rata PDRB Kota Jambi sejak tahun 2012 hingga tahun 2016 adalah sebesar 14.959.018,04 juta rupiah. Seluruh sektor mengalami kenaikan PDRB setiap tahunnya, kecuali sektor pertambangan dan penggalian yang mengalami penurunan sejak tahun 2015 dan 2016.

PDRB SERI 2010 ATAS DASAR HARGA KONSTAN MENURUT LAPANGAN USAHA KOTA JAMBI TAHUN 2010 - 2016 (JUTA RUPIAH)

\begin{tabular}{|c|c|c|c|c|c|c|c|}
\hline Kategori & Uraian & 012 & 2013 & 2014 & 2015 & 2016 & \begin{tabular}{|l|l|} 
Rata2 PDRB \\
\end{tabular} \\
\hline A & $\begin{array}{l}\text { Petranian, Kehutanan, } \\
\text { dan Perikanan }\end{array}$ & $160,061.80$ & $167,004.30$ & $176,100.20$ & 180,644.70 & $183,855.40$ & $173,533.28$ \\
\hline B & $\begin{array}{l}\text { Pertambangan dan } \\
\text { Pengagalian }\end{array}$ & $9,002.90$ & $760,239.30$ & $766,189.10$ & $595,342.30$ & $578,341.10$ & $687,822.94$ \\
\hline c & Industri Pengolahan & 651,457.10 & $1,751,315.10$ & $1,866,508.20$ & $1,962,940.80$ & $2,045,889.00$ & $855,622$. \\
\hline D & $\begin{array}{l}\text { Pengadaan Listrik dan } \\
\text { Gas }\end{array}$ & $21,569.20$ & 23,517.50 & 27,639.60 & $29,450.50$ & $31,178.20$ & 26,671.00 \\
\hline $\mathrm{E}$ & \begin{tabular}{l|} 
Pengadaan Air, \\
Pengelolaan Sampah, \\
Limbah dan Daur Ulang \\
\end{tabular} & 38,233.90 & 38,816.90 & 40,081.30 & . 270.40 & 42,990.40 & 40,278 \\
\hline $\mathrm{F}$ & Konstruksi & 90 & 0 & 50 & 70 & $678,659.80$ & 421,828 \\
\hline G & $\begin{array}{l}\text { Perdagang } \\
\text { Eceran; R } \\
\text { dan Seped }\end{array}$ & $3,039,039.40$ & $3,318,509.60$ & 763,510.20 & $9,918.00$ & $4,544,458.60$ & 3,777 \\
\hline H & Transpor & $1,606,566.50$ & $44,401.70$ & $87,577.50$ & $1,995,122.50$ & 842.80 & $1,895,302$ \\
\hline 1 & $\begin{array}{l}\text { Penyedia } \\
\text { dan Mak }\end{array}$ & $263,445.80$ & $0,183.70$ & $336,428.70$ & $350,227.20$ & $379,073.80$ & 321,871 \\
\hline J & Informas & $648,472.90$ & 3,712.00 & $9,840.20$ & $776,304.70$ & $843,486.10$ & $732,363.18$ \\
\hline k & $\begin{array}{l}\text { Jasa Keuangan } \\
\text { Asuransi }\end{array}$ & $793,173.60$ & $889,807.90$ & 919,657.90 & $936,666.30$ & $1,050,080.20$ & $917,877.18$ \\
\hline L & Real Estate & 669.80 & 50 & 461.30 & 01150 & $1,727.50$ & $391,111.32$ \\
\hline$\overline{\mathrm{M}, \mathrm{N}}$ & Jasa Peru & 549.10 & 1288.80 & $8,398.70$ & $6,930.10$ & $6,179.40$ & $424,037.2$ \\
\hline 0 & \begin{tabular}{l|} 
Administrasi \\
Pemerintahan, \\
Pertahanan dan Jaminan \\
Sosial Wajib \\
\end{tabular} & $985,000.20$ & ;,211.80 & $1,142,178.90$ & $1,215,546.10$ & $1,251,814.40$ & $1,118,192.28$ \\
\hline$P$ & Jasa Pen & $7,201.30$ & $665,362.70$ & 50 & t., & $771,534.50$ & $696,763.32$ \\
\hline Q & $\begin{array}{l}\text { Jasa Kes } \\
\text { Kegiatan }\end{array}$ & $284,804.50$ & $315,471.80$ & $364,416.90$ & $401,894,30$ & $430,571.10$ & $359,431.72$ \\
\hline$\overline{\mathrm{S}, \mathrm{T}, \mathrm{U}}$ & Jasala & & $2,315.10$ & 5068 & 25,23 & $133,095.90$ & $119,224,60$ \\
\hline
\end{tabular}

Pembagian PDRB berdasarkan pada lapangan usaha dikategorikan menjadi 17 kategori. Kelompok kategori yang memiliki nilai PDRB tertinggi adalah:

1. Kategori G, yaitu perdagangan bebas dan eceran; Reparasi mobil dan motor.

2. Kategori $\mathrm{H}$, yaitu transportasi dan pergudangan.

3. Kategori C, yaitu industri pengolahan.

4. Kategori F, yaitu konstruksi.

5. Kategori O, yaitu administrasi pemerintahan, pertahanan dan jaminan sosial wajib.

Sedangkan kelompok kategori yang memiliki nilai PDRB terendah adalah:

1. Kategori D, yaitu pengadaan listrik dan gas.

2. Kategori E, yaitu pengadaan air, pengelolaan sampah, limbah dan daur ulang.

3. Kategori RSTU, yaitu jasa lainnya.

4. Kategori A, yaitu pertanian, kehutanan, dan perikanan.

5. Kategori I, yaitu penyediaan akomodasi dan makan minum.

Nilai peringkat PDRB untuk masing-masing sektor pada tahun 2012-2016, dapat dilihat pada tabel di bawah ini: 


\section{Peringkat PDRB Terendah dan Tertinggi}

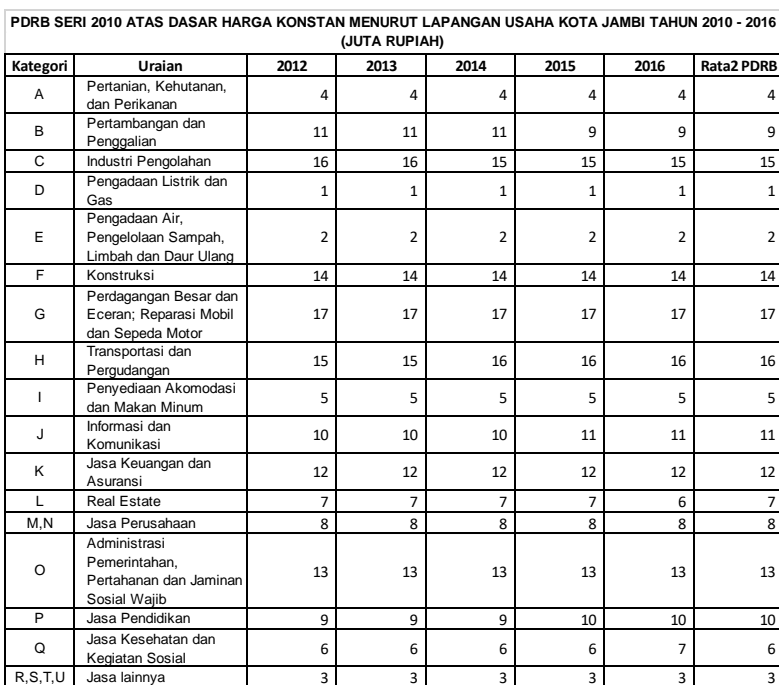

Berdasarkan pada tabel di atas, nomor 1 menandakan PDRB terendah dan nomor 17 menandakan PDRB tertinggi. Data di atas menunjukkan bahwa hampir semua sektor berada pada peringkat PDRB yang sama jika dibandingkan dengan total PDRB. Beberapa sektor yang mengalami kenaikan dan penurunan diantara-nya adalah:

\section{Kenaikan Penurunan PDRB 2012-2016}

\begin{tabular}{|l|l|}
\hline \multicolumn{1}{|c|}{ SEKTOR } & \multicolumn{1}{c|}{ KETERANGAN } \\
\hline B. Pertambangan dan Penggalian & turun sejak tahun 2015 \\
\hline C. Industri Pengolahan & turun sejak tahun 2014 \\
\hline H. Transportasi dan Pergudangan & naik sejak tahun 2014 \\
\hline J. Informasi dan Komunikasi & naik sejak tahun 2015 \\
\hline L. Real Estate & turun pada tahun 2016 \\
\hline P. Jasa Pendidikan & naik sejak tahun 2015 \\
\hline Q. Jasa Kesehatan dan Kegiatan Sosial & naik pada tahun 2016 \\
\hline
\end{tabular}

\subsection{Laju Pertumbuhan Ekonomi di Kota Jambi}

Laju pertumbuhan ekonomi di Kota Jambi bisa terlihat dari pertumbuhan nilai PDRB sejak tahun 20122016, yang bisa terlihat pada tabel di bawah ini:

Laju Pertumbuhan PDRB Tahun 2012-2016

\begin{tabular}{|c|c|c|c|c|c|}
\hline \multirow{2}{*}{ PDRB NON MIGAS } & \multicolumn{5}{|c|}{ LAJU PERTUMBUHAN PDRB SERI 2010 MENURUT LAPANGAN USAHA (Persen) } \\
\hline & 2012 & 2013 & 2014 & 2015 & 2016 \\
\hline A Pertanian, Kehutanan, Perikanan & 3.89 & 4.34 & 5.45 & 2.58 & 1.78 \\
\hline B. Perrambangan dan Penggalian & 1.55 & 2.87 & 0.78 & -22.3 & -2.86 \\
\hline C. Industri Pengolahan & 7.62 & 6.05 & 6.58 & 5.17 & 4.23 \\
\hline D. Pengadaan Listrik dan Gas & 11.6 & 9.03 & 17.53 & 6.55 & 5.87 \\
\hline $\begin{array}{l}\text { E. Pengadaan Air, Pengelolaan Sampah, } \\
\text { Limbah dan Daur Ulang }\end{array}$ & 1.05 & 1.52 & 3.26 & 2.97 & 4.17 \\
\hline F. Konstruksi & 16.74 & 27.58 & 4.07 & 2.5 & 4.13 \\
\hline $\begin{array}{l}\text { G. Perdagangan Besar dan Eceran; } \\
\text { Reparasi Mobil dan Sepeda Motor }\end{array}$ & 8.81 & 9.2 & 13.41 & 12.13 & 7.69 \\
\hline H. Transportasi dan Pergudangan & 9.01 & 8.58 & 8.21 & 5.7 & 12.42 \\
\hline $\begin{array}{l}\text { I. Penyediaan Akomodasi dan Makan } \\
\text { Minum }\end{array}$ & 9.02 & 6.35 & 20.07 & 4.1 & 8.24 \\
\hline J. Informasi dan Komunikasi & 2.17 & 5.43 & 3.82 & 9.36 & 8.65 \\
\hline K. Jasa Keuangan dan Asuransi & 11.18 & 12.18 & 3.35 & 1.85 & 12.11 \\
\hline L. Real Estate & 5.33 & 4.2 & 4.02 & 2.43 & 4.9 \\
\hline M,N. Jasa Perusahaan & 4.3 & 2.49 & 6.16 & 6.82 & 6.54 \\
\hline $\begin{array}{l}\text { O. Administrasi Pemerintahan, Pertahanan } \\
\text { dan Jaminan Sosial Wajilb }\end{array}$ & 3.02 & 1.16 & 14.63 & 6.42 & 2.98 \\
\hline P. Jasa Pendidikan & 7.71 & 2.81 & 1.32 & 7.64 & 6.33 \\
\hline Q. Jasa Kesehatan dan Kegiatan Sosial & 4.39 & 10.77 & 15.51 & 10.28 & 7.14 \\
\hline $\mathrm{R}, \mathrm{S}, \mathrm{T}, \mathrm{U}$. Jasa lainnya & 3.16 & 2.56 & 3.25 & 7.99 & 6.28 \\
\hline
\end{tabular}

\subsection{Analisis Tipologi Klassen}

Analisis Tipologi Klassen merupakan salah satu cara yang dapat dilakukan dalam memetakan data PDRB hingga menjadi kelompok-kelompok tertentu yang akan menggambarkan potensi daerah secara sektoral. Teknik dihitung dengan membandingkan antara pertumbuhan daerah dengan kontribusi sektorsektor tertentu terhadap PDRB di daerah tersebut. Berdasarkan pada data PDRB dan laju pertumbuhan Kota Jambi, maka pengelompokan potensi daerah disajikan pada tabel di bawah ini:

\begin{tabular}{|c|c|c|c|c|c|}
\hline \multicolumn{6}{|c|}{ ANALISIS TIPOLOGI KLASSEN } \\
\hline Kategori & Uraian & Rata2 PDRB & rata-rata laju & & Sektor \\
\hline A & $\begin{array}{l}\text { Pertanian, Kehutanan, dan } \\
\text { Perikanan }\end{array}$ & $173,533.28$ & 3.61 & 4 & sektor terbelakang \\
\hline B & Pertambangan dan Penggalian & $687,822.94$ & (3.99) & 4 & sektor terbelakang \\
\hline c & Industri Pengolahan & $1,855,622.04$ & 5.93 & 1 & sektor unggulan \\
\hline D & Pengadaan Listrik dan Gas & $26,671.00$ & 10.12 & 1 & sektor unggulan \\
\hline $\mathrm{E}$ & $\begin{array}{l}\text { Pengadaan Air, Pengelolaan } \\
\text { Sampah. Limbah dan Daur Ulang }\end{array}$ & $40,278.58$ & 2.59 & 1 & sektor unggulan \\
\hline $\mathrm{F}$ & Konstruksi & $1,421,828.32$ & 11.00 & 1 & sektor unggulan \\
\hline G & $\begin{array}{l}\text { Perdagangan Besar dan Eceran; } \\
\text { Reparasi Mobil dan Sepeda Motor }\end{array}$ & $3,777,087.16$ & 10.25 & 1 & sektor unggulan \\
\hline $\mathrm{H}$ & Transportasi dan Pergudangan & $1,895,302.20$ & 8.78 & 1 & sektor unggulan \\
\hline 1 & $\begin{array}{l}\text { Penyediaan Akomodasi dan } \\
\text { Makan Minum }\end{array}$ & $321,871.84$ & 9.56 & 1 & sektor unggulan \\
\hline J & Informasi dan Komunikasi & $732,363.18$ & 5.89 & 1 & sektor unggulan \\
\hline $\mathrm{K}$ & Jasa Keuangan dan Asuransi & $917,877.18$ & 8.13 & 1 & sektor unggulan \\
\hline $\mathrm{L}$ & Real Estate & $391,111.32$ & 4.18 & 1 & sektor unggulan \\
\hline $\mathrm{M}, \mathrm{N}$ & Jasa Perusahaan & $424,037.22$ & 5.26 & 1 & sektor unggulan \\
\hline 0 & $\begin{array}{l}\text { Adminisitrasi Pemerintahan, } \\
\text { Pertahanan dan Jaminan Sosial } \\
\text { Wajib }\end{array}$ & $1,118,192.28$ & 5.64 & 1 & sektor unggulan \\
\hline $\mathrm{P}$ & Jasa Pendidikan & $696,763.32$ & 5.16 & 1 & sektor unggulan \\
\hline Q & $\begin{array}{l}\text { Jasa Kesehatan dan Kegiatan } \\
\text { Sosial }\end{array}$ & $359,431.72$ & 9.62 & 1 & sektor unggulan \\
\hline $\mathrm{R}, \mathrm{S}, \mathrm{T}, \mathrm{U}$ & Jasa lainnya & $119,224.60$ & 4.65 & 1 & sektor unggulan \\
\hline PROD & JK DOMESTIK REGIONAL BRUTO & $879,942.24$ & 6.26 & & \\
\hline
\end{tabular}

Berdasarkan pada analisis Tipologi Klassen di atas, maka seluruh sektor yang ada di Kota Jambi terkelompok menjadi 2 (dua) sektor, yaitu:

1. Sektor terbelakang, terdiri dari sektor A dan B.

Sektor yang masuk dalam sektor ini adalah sektor pertambangan dan penggalian serta sektor pertanian, kehutanan, dan perikanan. Kedua sektor tersebut merupakan sektor yang memberikan kontribusi paling rendah terhadap PDRB Kota Jambi. Jika dihubungkan dengan potensi desa, maka sektor ini masuk ke kuadran IV, adalah kondisi yang perlu dihindari, dikarenakan potensi yang dimiliki oleh sektor ini rendah, dan pemerintah tidak memiliki kemampuan yang cukup untuk mengelola sektor ini hingga dapat memberikan kontribusi pendapatan kepada daerah. Pemerintah daerah yang memiliki sektor pada kuadran ini harus mengambil langkah strategi untuk melakukan banyak-banyak program pelatihan agar masyarakatnya mempunyai kemampuan untuk mengelola sumber daya alamnya dengan baik. Walikota Jambi harus berupaya agar sektor-sektor yang masuk dalam kategori ini cepat berkembang dan dapat pindah ke posisi kuadran III, dengan terus mengupayakan perbaikan kompetensi sumber daya manusia di daerahnya.

2. Sektor unggulan, terdiri dari sektor C, D, E, F, G, H, I, J, K, L, M, N, O, P, Q. dan R, S, T, U.

Hal ini menunjukkan bahwa sektor-sektor tersebut di atas adalah sektor yang paling dominan 
memberikan peningkatan PDRB sehingga berdampak terhadap perekonomian Kota Jambi. Jika dihubungkan dengan peta potensi daerah, maka sektor ini masuk dalam kondisi ideal atau Kuadran I dikarenakan daerah tersebut memiliki potensi pendapatan yang besar dari sektor-sektor tersebut dan ditambah lagi dengan adanya kemampuan daerah yang tinggi untuk mengelola seluruh sektor tersebut. Namun demikian, pemerintah juga tetap harus waspada dan tidak terlena dengan kontribusi dari sektor-sektor ini, karena jika sektor ini terus dikuras tanpa adanya regenerasi di setiap sektor, maka akan terjadi pengurangan bahkan pemusnahan dari sumbersumber sektor tersebut. Oleh karena itu, pemerintah harus mampu untuk terus melakukan upaya agar sektor-sektor tersebut jangan terlalu dieksploitasi secara bebas, khususnya yang bersumber dari sumber daya alam, agar dapat meningkatkan pendapatan fiskal daerah secara berkesinambungan.

\subsection{Realisasi Pajak Daerah berdasarkan Laporan Hasil Pemeriksaan Badan Pemeriksa Keuangan (LHP BPK)}

Pemerintah Kota Jambi sebagai salah satu instansi pemerintah wajib diaudit oleh auditor internal dan eksternal pemerintah. Auditor internal pemerintah diantaranya adalah Inspektorat dan Badan Pengawas Keuangan dan Pembangunan (BPKP). Auditor eksternal pemerintah adalah BPK. Hasil audit BPK tertuang dalam Laporan Auditor Independen, yang menyatakan pendapat atas kewajaran laporan keuangan. Hasil pendapat dalam bentuk opini atas laporan keuangan pemerintah Kota Jambi adalah sebagai berikut:

1. Tahun 2012 menerima opini Wajar Dengan Pengecualian.

2. Tahun 2013 menerima opini Wajar Dengan Pengecualian.

3. Tahun 2014 menerima opini Wajar Dengan Pengecualian.

4. Tahun 2015 menerima opini Tidak Menyatakan Pendapat.

5. Tahun 2016 menerima opini Wajar Tanpa Pengecualian.

6. Tahun 2017 menerima opini Wajar Tanpa Pengecualian.

Salah satu akun yang diaudit oleh BPK dalam Laporan Keuangan adalah akun pajak daerah yang merupakan salah satu sumber pendapatan daerah. Realisasi pajak daerah disajikan secara rekapitulasi pada tabel di bawah ini:
Realisasi Pajak Daerah Kota Jambi

Tahun 2012-2017 (Dalam Rupiah)

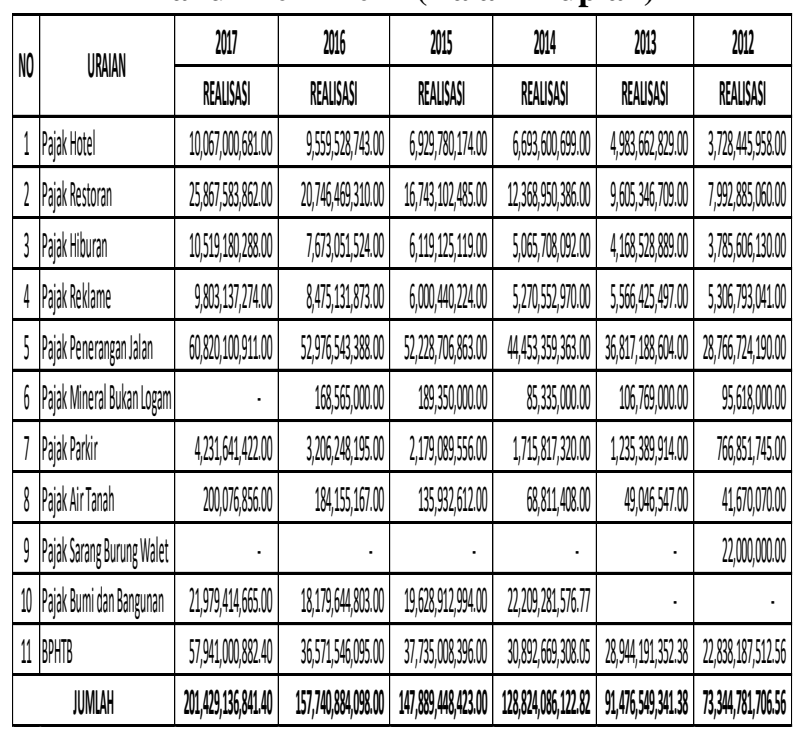

Berdasarkan pada tabel di atas, terlihat bahwa pajak daerah Kota Jambi mengalami peningkatan setiap tahunnya. Pajak daerah dipungut berdasarkan UndangUndang Republik Indonesia Nomor 28 Tahun 2009 tentang Pajak Daerah dan Retribusi Daerah dan diturunkan ke dalam Peraturan Daerah Kota Jambi Nomor 7 tahun 2016 tentang Perubahan atas Peraturan Daerah Nomor 5 tahun 2011 tentang Pajak Daerah.

Tabel di bawah ini menunjukkan persentase masing-masing pajak. Pajak tertinggi adalah pajak penerangan jalan, BPHTB, dan pajak restoran.

\section{Persentase Pajak Daerah}

\begin{tabular}{|c|c|c|c|c|c|c|c|}
\hline NO & URAIAN & 2017 & 2016 & 2015 & 2014 & 2013 & 2012 \\
\hline 1 & Pajak Hotel & $5.00 \%$ & $6.06 \%$ & $4.69 \%$ & $5.20 \%$ & $5.45 \%$ & $5.08 \%$ \\
\hline 2 & Pajak Restoran & $12.84 \%$ & $13.15 \%$ & $11.32 \%$ & $9.60 \%$ & $10.50 \%$ & $10.90 \%$ \\
\hline 3 & Pajak Hiburan & $5.22 \%$ & $4.86 \%$ & $4.14 \%$ & $3.93 \%$ & $4.56 \%$ & $5.16 \%$ \\
\hline 4 & Pajak Reklame & $4.87 \%$ & $5.37 \%$ & $4.06 \%$ & $4.09 \%$ & $6.09 \%$ & $7.24 \%$ \\
\hline 5 & Pajak Penerangan Jalan & $30.19 \%$ & $33.58 \%$ & $35.32 \%$ & $34.51 \%$ & $40.25 \%$ & $39.22 \%$ \\
\hline 6 & Pajak Mineral Bukan Logam & $0.00 \%$ & $0.11 \%$ & $0.13 \%$ & $0.07 \%$ & $0.12 \%$ & $0.13 \%$ \\
\hline 7 & Pajak Parkir & $2.10 \%$ & $2.03 \%$ & $1.47 \%$ & $1.33 \%$ & $1.35 \%$ & $1.05 \%$ \\
\hline 8 & Pajak Air Tanah & $0.10 \%$ & $0.12 \%$ & $0.09 \%$ & $0.05 \%$ & $0.05 \%$ & $0.06 \%$ \\
\hline 9 & Pajak Sarang Burung Walet & $0.00 \%$ & $0.00 \%$ & $0.00 \%$ & $0.00 \%$ & $0.00 \%$ & $0.03 \%$ \\
\hline 10 & Pajak Bumi dan Bangunan & $10.91 \%$ & $11.53 \%$ & $13.27 \%$ & $17.24 \%$ & $0.00 \%$ & $0.00 \%$ \\
\hline 11 & BPHTB & $28.76 \%$ & $23.18 \%$ & $25.52 \%$ & $23.98 \%$ & $31.64 \%$ & $31.14 \%$ \\
\hline & JUMLAH & $00.00 \%$ & $100.00 \%$ & $100.00 \%$ & $100.00 \%$ & $100.00 \%$ & $100.00 \%$ \\
\hline
\end{tabular}

\subsection{Analisis Potensi Pajak Daerah Kota Jambi}

Berdasarkan pada tingkat PDRB, 5 (lima) sektor yang memiliki nilai PDRB tertinggi dan masuk dalam sektor unggulan, yaitu:

1. Kategori G, yaitu perdagangan bebas dan eceran; Reparasi mobil dan motor.

Yang masuk dalam kelompok ini adalah penjualan yang dilakukan tanpa melakukan perubahan teknis baik yang dilakukan baik dalam perdagangan bebas maupun perdagangan eceran, dengan mendapatkan keuntungan dari transaksi penjualan tersebut. Kategori ini juga mencakup reparasi mobil dan sepeda motor.

Kategori ini terdiri dari: 
a. Perdagangan, Reparasi, dan Perawatan Mobil dan Sepeda Motor.

b. Perdagangan Besar dan Eceran, bukan Mobil dan Sepeda Motor.

2. Kategori $\mathrm{H}$, yaitu transportasi dan pergudangan.

Kategori ini mencakup penyediaan angkutan penumpang atau barang, baik yang berjadwal maupun tidak, dengan menggunakan rel, saluran pipa, jalan darat, air atau udara dan kegiatan yang berhubungan dengan pengangkutan. Kategori Transportasi dan Pergudangan terdiri atas: angkutan rel; angkutan darat; angkutan laut; angkutan sungai, danau dan penyeberangan; angkutan udara; pergudangan dan jasa penunjang angkutan, pos dan kurir. Kegiatan pengangkutan meliputi kegiatan pemindahan penumpang dan barang dari suatu tempat ke tempat lainnya dengan menggunakan alat angkut atau kendaraan, baik bermotor maupun tidak bermotor. Sedangkan jasa penunjang angkutan mencakup kegiatan yang sifatnya menunjang kegiatan pengangkutan seperti: terminal, pelabuhan, pergudangan, dan lain-lain.

Sub kategori ini adalah:

a) Angkutan Rel

b) Angkutan Darat

c) Angkutan Laut

d) Angkutan Sungai, Danau, dan Penyeberangan.

3. Kategori C, yaitu industri pengolahan.

Kategori Industri Pengolahan meliputi kegiatan ekonomi di bidang perubahan secara kimia atau fisik dari bahan, unsur atau komponen menjadi produk baru. Bahan baku industri pengolahan berasal dari produk pertanian, kehutanan, perikanan, pertambangan atau penggalian seperti produk dari kegiatan industri pengolahan lainnya. Perubahan, pembaharuan atau rekonstruksi yang pokok dari barang secara umum diperlakukan sebagai industri pengolahan. Unit industri pengolahan digambarkan sebagai pabrik, mesin atau peralatan yang khusus digerakkan dengan mesin dan tangan. Termasuk kategori industri pengolahan adalah perubahan bahan menjadi produk baru dengan menggunakan tangan, kegiatan penjualan produk yang dibuat di tempat yang sama di mana produk tersebut dijual dan unit yang melakukan pengolahan bahan-bahan dari pihak lain atas dasar kontrak.

Sub kategori ini terdiri dari:
a. Industri Pengolahan Batubara dan Pengilangan Minyak dan Gas Bumi
b. Industri Makanan dan Minuman
c. Industri Pengolahan Tembakau
d. Industri Tekstil dan Pakaian Jadi
e. Industri Kulit, Barang dari Kulit, dan Alas Kaki
f. Industri Kayu, Barang dari Kayu dan Gabus, dan Barang Anyaman

g. Industri Kertas dan Barang dari Kertas, Percetakan, dan Reproduksi Media Rekam

h. Industri Kimia, Farmasi, dan Obat Tradisional

i. Industri Karet, Barang dari Karet, dan Plastik

j. Industri Barang Galian Bukan Logam

k. Industri Logam Dasar

1. Industri Barang Logam, Komputer, Barang Elektronik, Optik, dan Peralatan Listrik

m. Industri Mesin dan Perlengkapan

n. Industri Alat Angkutan

o. Industri Furnitur

p. Industri Pengolahan Lainnya, Jasa Reparasi, dan Pemasangan Mesin dan Peralatan

4. Kategori F, yaitu konstruksi.

Bentuk dari kategori ini adalah kegiatan usaha untuk melakukan pekerjaan bangunan dan gedung oleh masyarakat baik yang bersifat konstruksi umum atau khusus, yang digunakan sebagai sarana untuk melakukan aktivitas lain atau sebagai sarana tempat tinggal. Kategori ini terdiri dari konstruksi untuk melakukan pembangunan baru, penambahan atau perubahan, perbaikan, serta pendirian konstruksi yang bersifat sementara. Yang melakukan kegiatan ini biasanya dilakukan oleh kontraktor, baik kontraktor umum maupun khusus. Kontraktor umum adalah perusahaan yang kegiatannya untuk melakukan kegiatan konstruksi bagi pihak lain, sedangkan kontraktor khusus adalah individu untuk pembangunan milik pribadinya.

5. Kategori O, yaitu administrasi pemerintahan, pertahanan dan jaminan sosial wajib.

Yang termasuk dalam kategori ini adalah kegiatan-kegiatan yang berhubungan dengan pemerintahan, yang sifatnya adalah administrasi. Kategori ini juga mencakup per undangundangan dan penerjemahan hukum yang berkaitan dengan pengadilan dan menurut peraturannya, seperti halnya administrasi program berdasarkan peraturan per undang- undangan, kegiatan legislatif, perpajakan, pertahanan Negara, keamanan dan keselamatan Negara, pelayanan imigrasi, hubungan luar negeri dan administrasi program pemerintah, serta jaminan sosial wajib. Kegiatan yang diklasifikasikan di kategori lain dalam KBLI tidak termasuk pada kategori ini, meskipun dilakukan oleh Badan pemerintahan. Sebagai contoh administrasi sistim sekolah, (peraturan, pemeriksaan, dan kurikulum) termasuk pada kategori ini, tetapi pengajaran itu sendiri masuk kategori Pendidikan $(\mathrm{P})$ dan rumah sakit penjara atau militer diklasifikasikan pada kategori Q.

Berdasarkan pada 5 (lima) sektor PDRB tertinggi tersebut, Pemerintah Kota Jambi tidak dapat melakukan pungutan pajak daerah dikarenakan seluruh pajak daerah yang dipungut harus sesuai dengan undang-undang dan peraturan terkait. 
Namun demikian, Pemerintah Kota Jambi dapat melakukan upaya dalam mendorong peningkatan sub sektor agar bisa meningkatkan pemakaian lampu jalan, jumlah hotel, serta pemahaman dan keinginan wajib pajak untuk selalu melakukan pembayaran pajak atas penggunaan kendaraan bermotor yang digunakannya.

\section{SIMPULAN DAN SARAN}

\subsection{Simpulan}

1. PDRB di Kota Jambi mengalami kenaikan setiap tahunnya, dan semua sektor juga mengalami kenaikan kecuali sektor pertambangan.

2. PDRB tertinggi berada pada Kategori G, yaitu perdagangan bebas dan eceran; Reparasi mobil dan motor.

3. PDRB terendah berada pada Kategori D, yaitu pengadaan listrik dan gas.

4. Pengelompokan sektor di Kota Jambi dikelompokkan menjadi 2 sektor, yaitu sektor unggulan dan sektor terbelakang. Sektor-sektor yang merupakan bagian dari sektor terbelakang di Kota Jambi adalah sektor kehutanan, pertanian, Pertambangan dan Penggalian serta sektor Perikanan. Sedangkan sektor yang lain masuk dalam sektor unggulan.

5. Pajak daerah Kota Jambi selalu mengalami kenaikan tiap tahunnya berdasarkan pada data penerimaan pajak tahun 2012-2016. Pajak tertinggi diperoleh dari pajak penerangan jalan, BPHTB, dan pajak restoran.

6. Pemerintah Kota Jambi dapat meningkatkan pajak dari sektor terbelakang melalui program pendidikan tersistem dan pelatihan (edukasi) dalam upaya peningkatan kualitas sumber daya manusia sehingga mampu mengelola potensi pendapatan dengan kompetensi yang lebih baik. Untuk sektor unggulan pemerintah harus berupaya agar seluruh sumber pendapatan yang dimiliki dapat terjaga dengan baik sehingga mampu memberikan peningkatan kesinambungan keuangan untuk tiap generasi setiap periodenya.

\subsection{Saran}

1. Diharapkan agar penelitian selanjutnya dapat menelusuri potensi pajak daerah melalui data PDRB Sub sektor.

2. Pemerintah harus melakukan strategi agar pendapatan asli daerah dapat meningkat penerimaannya khususnya PAD yang diperoleh dari pajak daerah berdasarkan peta potensi daerah untuk masing-masing sektor dan sub sektor.

\section{DAFTAR REFERENSI}

Mahmudi. Manajemen Keuangan Daerah. 2010. Jakarta. Erlangga. 2010.

Mardiasmo. Perpajakan Edisi Revisi. 2011 .Yogyakarta: Penerbit Andi. 2011.

Undang Undang Nomor 33 Tahun 2004 tentang Pertimbangan Keuangan Antara Pusat dan Daerah.

Undang-Undang Nomor 28 tahun 2009 tentang Pajak dan Retribusi Daerah 